\title{
CD59 Gene
}

National Cancer Institute

\section{Source}

National Cancer Institute. CD59 Gene. NCI Thesaurus. Code C95932.

This gene is involved in the modulation of the complement cascade. 